\title{
Morphotaxonomic characteristics of Hymenolepis mehrabpurensis N. sp., from (Turdoides striata, 1823 Leiothrichidae) of the tropical region, Sindh-Pakistan
}

\author{
Wali Muhammad Mangrio ${ }^{1}$, Hakim Ali Sahito ${ }^{1,2^{*}}$, Tasneem Kousar ${ }^{1}$, \\ Zafar Hussain Shah ${ }^{1}$ and Faheem Ahmed Jatoi ${ }^{1}$ \\ 1. Department of Zoology, Faculty of Natural Sciences, Shah Abdul Latif University, Khairpur Mir's, 66020 \\ Sindh-Pakistan \\ 2. Date Palm Research Institute (DPRI), Shah Abdul Latif University, Khairpur Mir's, 66020 Sindh-Pakistan \\ *Corresponding author's email: hakim.sahito@salu.edu.pk \\ Citation \\ Wali Muhammad Mangrio, Hakim Ali Sahito, Tasneem Kousar, Zafar Hussain Shah and Faheem Ahmed Jatoi. \\ Morphotaxonomic characteristics of Hymenolepis mehrabpurensis N. sp., from (Turdoides striata, 1823 \\ Leiothrichidae) of the tropical region, Sindh-Pakistan. Pure and Applied Biology. Vol. 9, Issue 1, pp979-988. \\ http://dx.doi.org/10.19045/bspab.2020.90103
}

\begin{tabular}{|c|c|c|c|}
\hline Received: 12/10/2019 & Revised: 31/12/2019 & Accepted: 02/01/2020 & Online First: $10 / 01 / 2020$ \\
\hline
\end{tabular}

\section{Abstract}

Sindh province having own unique identification due to historical Indus civilization and River Indus but research work was conducted at district: Naushahro Feroze, which is a most imperative sahati region of central Sindh and comprises mostly agriculture-based lands. For prevalence of helminth parasitic burden in Jungle babbler, a total no of $(\mathrm{n}=12) T$. striata were collected from Taluka, Mehrabpur, during 2017-18 and $(n=86)$ specimen were recovered belonging to the genus; Hymenolepis Weinland, 1858 which were recovered from intestine and clocal opening. Whole specimens were pragmatic morphologically change, having larger opaque body and maximum width at gravid segments. Whitish delicate, long muscular scolexes, rostellum with rostellular sac contained four hooks in a single row, neck with 246, gravid 190 and mature proglottids 56 in number. All segments found wider than long, muscular suckers similar in length. Dome-shaped ovary, compact and irregular vitelline glands, cirrus sac is proturated outward, vagina situated behind the ovary, eggs oval-shaped and testes three to five in number. Actually, duration of present work was 12 months but high intensity of infection recorded in the month of January and minimum in June, by consequent difference compared $(P<0.05)$ cold and hot summer seasons. The present findings suggest that more work should be carried out other former friendly Aves in this region. This is a new documentary and new record documented first time over the helminth parasites in above mentioned region.

Keywords: Cirrus sac; Hymenolepis; Proglottids; Rostellum; T. striata; Vitelline glands

\section{Introduction}

Birds, the most attractive creature including more than 10,000 species [1], majority of them found in continental regions remaining in islands. Pakistan comprises Oriental and Palearctic regions in both areas 670 species and 74 families of avifauna are found [2], about 356 bids 
species have been documented in Sindh of which 17 species are at endangered conditions [3]. Surrounding the Indus Delta region 329 species are surviving [4]. These are traditionally divided into 30 to 40 orders [5]. The Passeriformes are commonly song producing beautiful and perching vertebrates. They are warmblooded, oviparous and their eggs contain calcium carbonated porous shell. In Pakistan wide range of fauna are serving their life due to the fruitful location and diverse habitats. Geese, waders, ducks, flamingos cranes, falcons, and swans are commonly migratory birds migrate towards Pakistan from European and Asian regions follow a zone known as Indus flyway or green route/root no. 4 [6]. Many scholars used their stamina to report helminth parasites of avifauna at Sindh region $[7,8,9]$.

T. striata are Passeriformes insectivorous endemic [10], locally called Saath Bhai in regional languages, commonly seen where scrub forests and plenty of food intermixed is available [11]. They are considered farmer-friendly because they feed on variety of pest insects, their eggs and larvae. However; these species serve their life in social grouping manner and taking the advantages from their association, they are co-operative breeders, varies in their number from 7 to 20 [12]. Male Jungle babbler is dominant over the female breeders [13]. Being gregarious and social they form intermixed foraging flock and eat berries, nectars, and grains [14]. They are long-lived predators [15]. Young birds contain dark iris but older having pale creamy-colored iris with dark epithelium [16], at the age of three years they attain maturity and breed in both seasons. By forming social allopreening they produce different voices to communicate among themselves such as; chases, chattering, chirping, squeaking, and mock flights [17]. Generally before dawn they wake up and move to screech for foraging but death occurs when they threatened by predators [18]. They are unable to fly at long distance [19]. They lay two to four eggs and after 14 to 16 days eggs become hatch but some other species are predators for their eggs i.e., greater coucal, crows and mongoose they also attack their young ones, including rat snake harm their chicks [20].

Majority of the beautiful birds are resilient numerous helminths including trematodes, nematodes, acanthocephalans but cestodes are frequently found at high prevalence, all these helminths are responsible for clinical and subclinical symptoms. Mostly worms affect intestinal part and they release their eggs in host faecal material for the purpose to re-infection in same species when reinfection occurs by the same type of helminths then birds show signs such as, diarrohea, poor health, reduce their body weight, certain illness conditions which may lead to death. Also during infection parasites rely badly effects to their hosts, unthriftiness, retarded growth, damage to the gut epithelium, lowering the gastro resistance against other infections, emaciation, lower production of eggs and may death occur to their hosts [21]. Speckled Pigeon, Columba guinea was examined by [22], from which recovered Monopolon gallinae $56 \%$ and Columbicola columbae $60 \%$, Hymeonolepis carica 13\%, R. cesticillus $26.7 \%$, Amoebotaenia cuneata $13 \%$, and Raillietina tetragona $3.3 \%$ respectively. A total of 136 common pigeons at Thessaloniki, Northern Greece, were examined found intestinal helminth infection in Columba livia domestica with $R$. cesticillus, $R$. echinobothrida, $R$. echinobothrida, $R$. cesticillus, and Raillietins spp., respectively. These species of helminths are able transmit in poultry, wild and domestic animals including humans [23]. At Ethiopia, intestinal parasites were recovered from chickens, i.e., C. infundibulum, $H$. carioca, $D$. proglottina, $R$. echinobothrida, $R$. cesticillus and $H$. contaniana at the percentage $13.7 \%, 17.7 \%, 8.1 \%, 63.7 \%$, $40.3 \%$ and $17.7 \%$, smiliarly, nematodes i. 
e., C. anatis, $H$. isolonche, A. suctoria, $H$. gallinarium, $H$. dispar, D. nasuta, $G$. ingluvicola and A. galli at 3.2\%, $8.9 \%$, $7.3 \%, 37.9 \%, 6.5 \%, 4.0 \%, 7.3 \%$ and $32.0 \%$, respectively [24]. Parasites of chicken in India were observed [25], documented low infection during winter compared to summer season and report Raillietina spp. and Ascaridia spp. Helminth parasites, cestodes species namely; $R$. tetragonal, Raillientina ransomi, $R$. echinobothrida, Chonotaenia infundibulum and $R$. cesticillus from chicken hosts and helminth were observed at the $45.9 \%, 29.7 \%, 18.9 \% 5.4 \%$, and $0.0 \%$, but in his examination broiler species were found free from the infection and highest prevalence of parasitic infection were recorded in backyards [26].

The Rooks, Ravens, Magpies, Crows, and Jays were examined and A. columbae cestodes recovered [27]. From the $A$. poecilorhyncha and $A$. brama host $P$. oxyurusis new parasite $P$. thapari was documented [28]. From the host Columba livia, helminth parasites, Eimeria sp., Raillietina, A. columbae and C. columbae at $31.0 \%, 9.0 \%, 33.3 \%$ and $17.4 \%$, were also observed by [29]. In Shaanxi province China, host bird Nipponia nippon, critically endangered species were examined and observed, Ascaris spp., Coccidea, C. caudiflata, Fasciolidae, Blastocysts spp., and E. histolytica at $84.2 \%, 7.8 \%, 50.0 \%, 23.7 \%, 15.8 \%$ and $7.8 \%$, respectively [30]. Gallus gallus spadiceus at Ulu Langat, Malaysia, were disected and recovered cestodes such as; $P$. canariensis, $P$. gallinum, Eimeria sp., $T$. fissispina, $C$. contorta, $R$. tetragona, $T$. gallinarium, $H$. cantaniana, $C$. nilesi, $H$. gallinarium, A. galli, $R$. cesticillus, D. spiralis, Gongylonema sp., and $C$. annulata but the population of Heterakis and Capillaria were observed high then other species [31]. Streptopelia senegalensis and Columbia livia of Lagos state, Nigeria were examined and cestodes helminths were found such as; $A$. columbae, $P$. columbae, $C$. columbae, $R$. tetragona, A. galli, G. gigag, M. Gallinae, and $R$. Echinobothrida, respectively. Columbicola columbae and Raillietina tetragona found frequently inside the host species and observed higher infection in doves than pigeons [32]. For this purpose, the research study was conducted from this region to check out the prevalence of new helminth species from present agrobeneficial host species in this tropical region for future planning to save the other passerine host birds.

\section{Material and methods}

T. striata were collected during 2017-18, for the purpose to examine internal organs to find out the prevalence of helminth parasites. A total $(n=12)$ host birds were captured form different locations including farmlands, villages, crop fields, surrounding the industries, towns, by the source of air gun and some purchased from local rural people and few from poultry forms and brought them Parasitology Laboratory, Zoology department, Shah Abdul Latif University, Khairpur for dissection. From intestinal region of all hosts $(n=86)$ specimen were recovered. If captured bird were supposed to be dead than on priority basis were kept in the refrigerator and first dissected those hosts which were injured by air gun and other birds were kept few days in wooden cage or iron made cage by supplying them nourishment and dissected under laboratory conditions as per need basis.

Firstly, cotton swab was taken by putting five to eight drops of chloroform hold for few minutes on both minute pores at the beak region with the help of one hand and intensively hold host with the help of another hand. When birds become completely anesthetized then feathers were removed from cloacal opening up to the neck region and a longitudinal cut was given by the source of scissors. Arranged petri plates by adding few amounts of distilled water and each segment of the visceral organs were kept in it individually. Adding few amounts of $100 \%$ ethanol in coplin jar and slides were 
poured for 16 to 18 minutes, then slide were taken for dehydration and with spongy pieces of cloth or handkerchief slides were sterilized. A stereo dissecting microscope very intensively used for examination of internal organs. Then the cestode specimen were laid on the slide covered with cover slip after that thorough threads were wrapped and again slides containing specimen placed inside coplin jar and left it for one night once again threads were reopened and in separate petri plate few amount of borax carmine were added parasite containing slide were placed inside the borax for mounting purpose until specimens were completely mount then parasites were washed with ethanol more than one time and two to three drops of Canada balsam were released by the help of dropper, now on the surface of fresh slide parasites were laid by putting them cover slip, then slide containing stained specimens were kept in oven box at least12-15 hours at fixed appropriate temperature. By the help of Camera Lucida diagram of the specimens were taken, finally, camera Meiji infinity, 1DK-3000 were used for photography and in millimetres $(\mathrm{mm})$ measurement of all internal organs of the helminths were tacked and in micrometers $(\mu \mathrm{m})$ eggs were measured. Holotype permanent slides of specimens were kept in Parasitology Laboratory, Department of Zoology, SALU, Khairpur for reference motivation.

\section{Statistical analysis}

For statistical examination total data was placed in Ms, excel, analysis of variation also for the purpose of authentic result help were also taken by using of SXW software, 8.1, version (USA).

\section{Results}

\section{The systematic position of Hymenolepis mehrabpurensis N. sp. (Fig. 1 \& 2)}

Family: Hymenolepididae Rilliet and Henery, 1910

Sub-family: Hymenolepidinae Perrier, 1897

Genus: $\quad H y m e n o l e p i s$ Weinland, 1858

Host: $\quad$ Turdoides striata

Location: Large intestine

Locality: Naushahro Feroze, Sindh-Pakistan.

No of hosts: 12
During research work 12 host birds were anesthetized and etically dissected all were found positive with cestode parasitic infection and their description is given as under:

\section{Description}

All specimens were recovered from the large intestine and near the cloacal opening of the host birds, cestode consists 1.11$1.18 \times 29.30-32.33$ by $1.19 \mathrm{~mm}$ in length and width but at gravid segments maximum width was observed. When cestodes were alive all specimens were found opaque, whitish and relatively delicate. Neck followed by 246 series of segments, comprises 0.25 to 0.78 . Wider then long muscular scolex consist 0.11$0.12 \mathrm{X} 0.13-0.14$ in size. A single row consist four hooks in vertical position comprises 0.38-0.44 X 0.07-0.09 in size. Rostellular sac 0.83 by 0.104 in size and rostellum $0.02-0.03 \times 0.06-0.08$ in size were found. One hundred and ninety gravid segments were counted contain measurement $0.12-0.118 \times 0.31-0.33$ of which one hundred and fifty-six mature proglottids consist $1.12-1.15 \mathrm{X} 0.22-0.28$ but all segments were wider than long. Muscular suckers consists 0.03-0.04 X $0.06-0.07$ in size. Oval shaped compact and irregular vitelline gland measured $0.128-0.080 \mathrm{X} \quad 0.112-0.120$ in size. Portrayed outward cirrus sac measured $0.51-0.53 \times 0.12-0.15$ in size and domeshaped ovary contain $0.12-0.15 \times 0.13$ 0.17 in size. Behind the ovary vagina is situated measured $0.241-0.242$ by 0.112 0.055 in size. Size of eggs 0.01-0.02 X $0.02-0.03$, testes oval in shape three to five in number comprises $0.03-0.06 \mathrm{X}$ 0.030.08 same in size, respectively (Fig. 1). 
Specimens no: 86
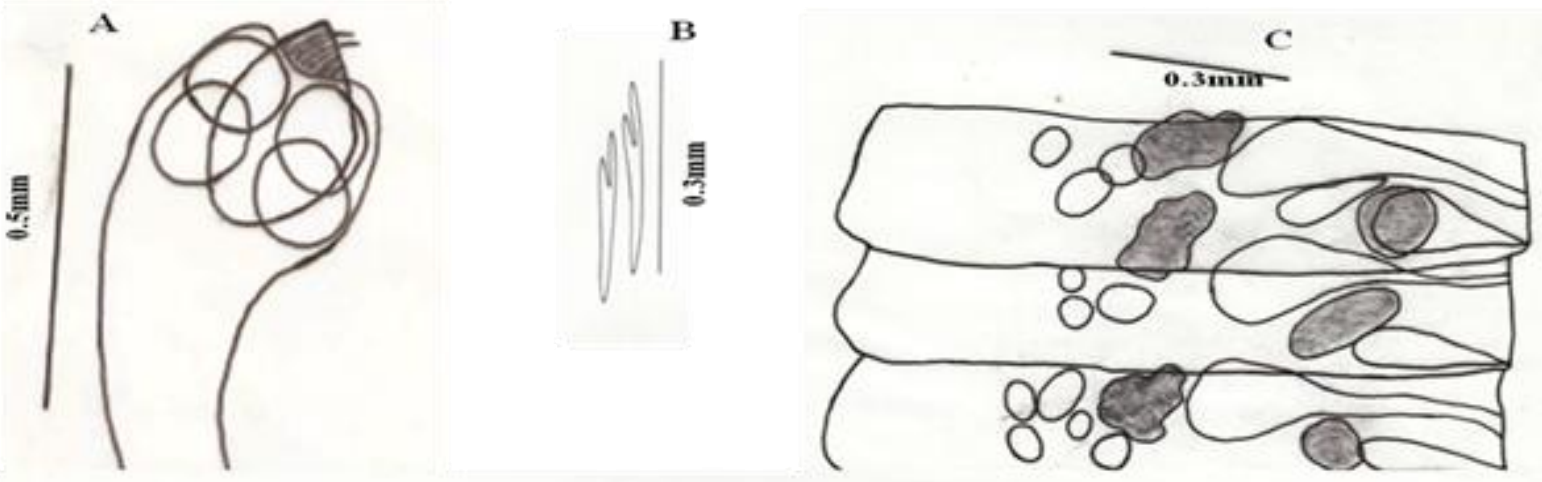

D

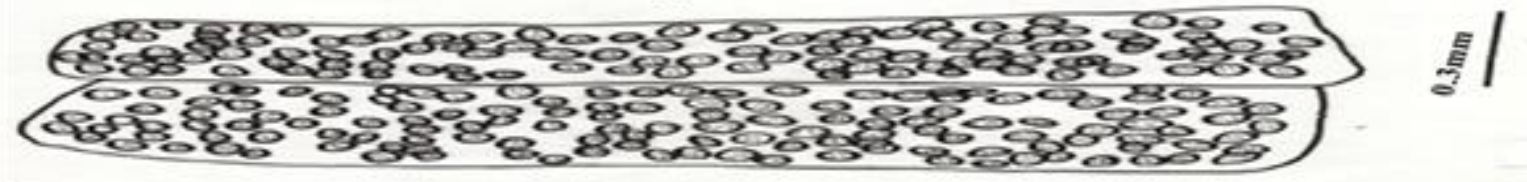

Figure 1. Hymenolepis mehrabpurensis N. sp., Scolex, Gravid segments, Hooks, Mature segments
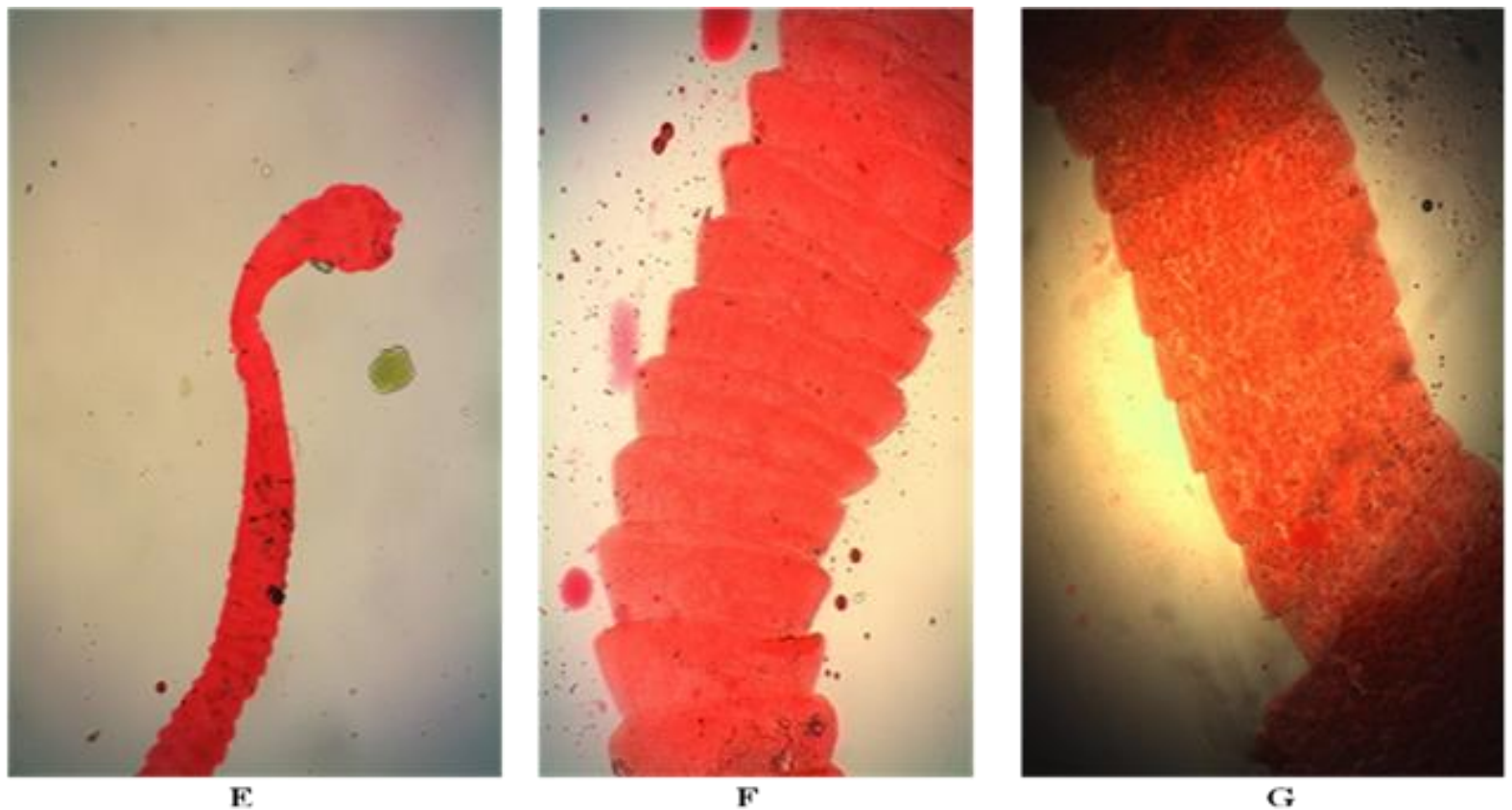

G

Figure 2. Photograph of Mature segment, Scolex, and Gravid segment

Hymenolepis mehrabpurensis n. sp., found different form Hymenolepis clausa, which was recovered from Columba livia at Lahore, H. medici, from Anas crecca, Peshawar, $H$. moghensis, from Anas crecca at Noweshera, $H$. megalorichis, from Anas crecca at Charsaddah, $H$. Lanceolata, from Anas crecca at Peshawar, Pakistan and $H$. uralensis, from
Anas crecca at Charsaddah, H. bilharzi and $H$. fringillarum, from Lanius senator niloticus at Gaza and $H$. pauciannulata, from Anas querquedula at Egypt.

On the basis of morphological characteristics such as; length, width, shape, and size of the hooks, ovary, testes, shape of the mature and immature proglottids, size and arrangement of the 
eggs and all other essential characteristics Hymenolepis mehrabpurensis n. sp., is proposed. New species were given new names from their locality where from host birds were captured. This species is first time reported from Sindh, Pakistan and Jungle babbler host birds is a new record for the genus Hymenolepis Weinland, 1858.

The present research work was conducted during the month of October 2017 to September 2018, a total of $(n=12)$ host birds $T$. striata were captured and only one host bird was dissected in every month for the prevalence of helminth intensity. The penalty examination demonstrates the greatest population was found in the month of January but the very less burden of helminth is observed in the month of June (Fig. 3). The investigation of discrepancy shows the momentous differentiation among 12 months of the year $(\mathrm{P}<0.05)$.

Table 1. Hymenolepis species body measurements and comparative morphological features under laboratory conditions

\begin{tabular}{|c|c|c|c|c|c|}
\hline Species & $\begin{array}{c}H . \\
\text { mehrabpuren } \\
\text { sis N.sp., }\end{array}$ & H. Clausa & H. medici & $\begin{array}{c}\mathrm{H} . \\
\text { megalorchi } \\
\mathrm{s}\end{array}$ & H. lanceolata \\
\hline Body & $\begin{array}{c}1.11-1.18 \mathrm{X} \\
29.30-32.33 \\
\text { by } 1.19\end{array}$ & $\begin{array}{c}111-114 \times 0.88- \\
0.92\end{array}$ & $0.26 \times 0.03$ & $0.26 \times 0.35$ & $19.4 \times 1.78$ \\
\hline Hooks & $\begin{array}{c}0.38-0.44 X \\
0.07-0.09\end{array}$ & $\begin{array}{c}10 \text { in number } 0.07- \\
0.09 \times 0.02-0.03\end{array}$ & 23 & 8 & 8 \\
\hline Neck & 0.25 to 0.78 . & $0.8 \times 1.6$ & Not-observed & 0.34 & Not-observed \\
\hline Scolex & $\begin{array}{c}0.11-0.12 \mathrm{X} \\
0.13-0.14\end{array}$ & $\begin{array}{c}0.23-0.32 \times 0.22- \\
0.25\end{array}$ & $1.24 \times 1.38$ & $\begin{array}{c}\text { Not- } \\
\text { observed }\end{array}$ & $0.28 \times 0.32$ \\
\hline Rostellum & $\begin{array}{l}0.02-0.03 X \\
0.06-0.08\end{array}$ & $0.07 \times 0.11$ & $0.27 \times 0.49$ & $0.05 \times 0.08$ & $0.06 \times 0.08$ \\
\hline Suckers & $\begin{array}{c}0.03-0.04 \mathrm{X} \\
0.06-0.07\end{array}$ & $0.11 \times 0.14$ & $0.45 \times 0.57$ & $0.12 \times 0.48$ & $0.13 \times 0.14$ \\
\hline Cirrus sac & $\begin{array}{l}0.51-0.53 X \\
0.12-0.15 \\
\end{array}$ & $\begin{array}{c}0.17-0.28 \times 0.05- \\
0.07\end{array}$ & Not-observed & $\begin{array}{c}\text { Not- } \\
\text { observed }\end{array}$ & Not-observed \\
\hline Ovary & $\begin{array}{c}0.12-0.15 X \\
0.13-0.17\end{array}$ & $0.04 \times 0.06$ & $0.09 \times 0.22$ & 0.07 X 0.08 & $0.09 \times 0.11$ \\
\hline Testes & $\begin{array}{c}0.03-0.06 \mathrm{X} \\
0.03-0.08\end{array}$ & $0.05 \times 0.06$ & $0.13 \times 0.12$ & $0.07 \times 0.11$ & $0.07 \times 0.08$ \\
\hline $\begin{array}{c}\text { Mature } \\
\text { segments }\end{array}$ & $\begin{array}{c}1.12-1.15 \mathrm{X} \\
0.22-0.28\end{array}$ & $\begin{array}{c}0.08-0-11 \times 0.29- \\
0.46\end{array}$ & $0.85 \times 0.96$ & $0.12 \times 0.44$ & 1.82 in length \\
\hline $\begin{array}{c}\text { Gravid } \\
\text { segments }\end{array}$ & $\begin{array}{c}0.12-0.118 \mathrm{X} \\
0.31-0.33 \\
\end{array}$ & $\begin{array}{c}0.12-0.18 \times 0.8- \\
0.11 \\
\end{array}$ & $0.18 \times 1.29$ & $0.02 \times 0.04$ & $0.33 \times 3.08$ \\
\hline Eggs & $\begin{array}{c}0.01-0.02 \mathrm{X} \\
0.02-0.03\end{array}$ & Abundant & $0.4 \times 0.5$ & Abundant & Abundant \\
\hline Host & Jungle babbler & Rock dove & Eurasian teal & $\begin{array}{c}\text { Green- } \\
\text { winged tail }\end{array}$ & Common teal \\
\hline Locality & $\begin{array}{l}\text { N. Feroze, } \\
\text { Sindh }\end{array}$ & Lahore & Peshawar & Charsaddah & Peshawar \\
\hline
\end{tabular}




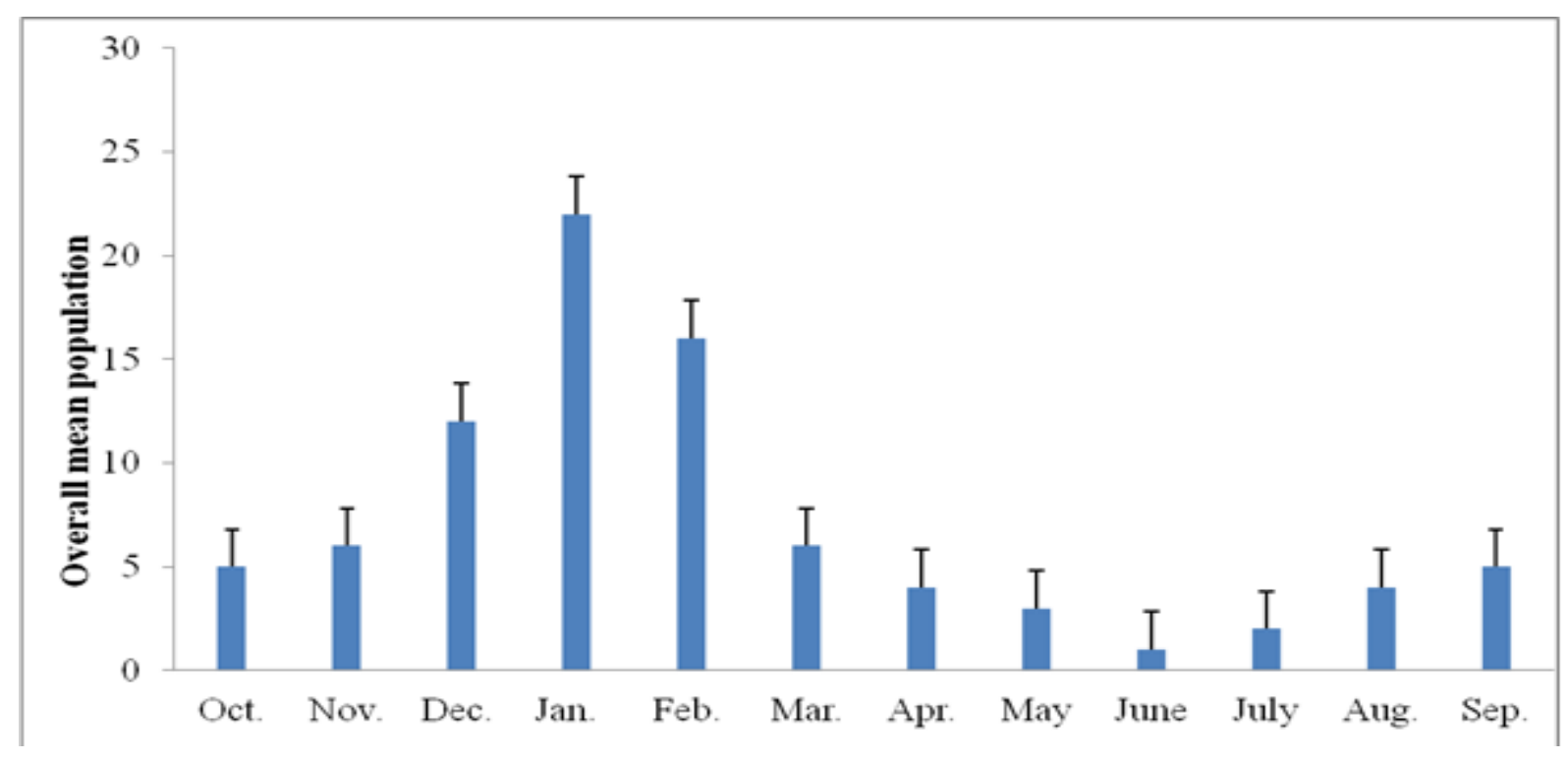

Figure 3. Prevalence of Hymenolepis mehrabpurensis N. sp., from Turdoides striata, 1823 (Leiothrichidae) a tropical region, province of Sindh

\section{Discussion}

The genus; Hymenolepis Weinland, 1858 was observed to documented cestode helminths of birds. Many other species of present genus; $H$. neoartica, collected from Sterna hirundo birds; from Anseriformes $H$. anatine, $H$. cornpressa and $H$. paracompressa collected from Aythya farina (L), Anas platyrhynchos (L), Querquedula querquedula (L), Aythya fuligula (L), Aythya marila (L), and Aythya rufa (L); $H$. fusus, $H$. cirros and $H$. megarostrellis from strunus vulgaris (L), Turdus viscivorus (L), Garrulus glandarius (L), Oriolus oviolus, Pica pica (L), Turdus merula (L), and Corvus splendens, cestode helminths $H$. farciminosa, were recovered from Anseriformes $H$. microsoma, $H$. megarostris, H. parina and $H$. passeris, from Corvus monedula (L), Corvus corone (L), Corvus frugilegus (L), Pica pica (L), Garrulus glandarius, Turdus torquatus (L), Turdus pilarius (L), Sturnus vulgaris (L), Turdus viscivorus and Turdus philomelos. H. serpentulus, were documented. From different species of passeriformes such as; Blue tit, House sparrow, Coal tit, Hedge sparrow and Chaffinch cestode $H$. fringillarum, were observed and from Ringed plover helminth $H$. rectacantha recovered. From Athya farina and Anas acuta, $H$. fausti and $H$. solowiow were reported. From Anas platyrhynchos (L) $H$. furcigera, from Gallinago gallinago (L) cestodes Hymenolepis sp., from Tringa ochropus host, $H$. hirsute and from Jackdaw, Rook, Magpie, Carrion crow and Jay H. stylosa were documented.

During dissection and internal examination, no any host is observed free from infection and high appearance is found in colder months as compares with hot summer and the result is formulated with the agreement of [33], who already worked on same host and established the prevalence of cestode worm Hymenolepis sp., (Weinland, 1858) from Turdoides striata of other talukas of the same district. The present research indicates that cestodes widely affect the birds but Jungle babbler cannot be examined properly in Pakistan. Although, a variety of birds had been investigated by many scholars for the prevalence of helminth parasites little work is conducted in perspective of wild birds [34].

Notably, from broiler poultry chickens at Maharashtra, India helminth Raillietina 
sp., and Ascarida sp., were found [35]. Columbidae was examined in Iran and recovered Phthiraptera, C. columbae [36]. At Nigeria chickens were dissected and recovered Raillientina spp., Strongyles spp., Heterakis spp., Ascaris and gallinarium cestodes [37]. Chickens were dissected at Murehwa, Zimbabwe and recovered, C. infundibulusm, A. cuneata, A. cuneata, Hymenolepis sp., and ectoparasites i-e., $E$. gallinacean, $C$. mutants, D. gallinae and A. persicus [38]. In cestode of Aves i-e., Capillaria sp., and A. galli and Acuaria sp., H. gallinae, A. galli may infect rib cage of the hosts [39]. Albendazole and fenbendazole are treatment effective sources for the prevention of cestode infection [40]. Furthermore, this kind of research was documented by [41-44], and from $T$. striata host recovered Lyperosomum longicauda (Rudolphi, 1809) at same region. This type of research was conducted first time to examine the helminth intensity of Jungle babblers.

\section{Conclusion}

T. striata birds are omnivores in their feeding behavior widely distributed in Asian countries, generally known as seven sisters, these species mostly feed pest insects, vertebrate pests and predators due to such type of nature commonly denoted as farmer-friendly. This kind of bird also harbors helminth parasites in their internal tract create morbidity; reduce population and causative reason for their high mortality. In this regard, present scientific documentary suggests more research and systematic study should be carried out on the internal helminth parasites of Leiothrichidae because there is no particular record or scientific documentary regarding cestode helminth in $T$, striata, at the above-mentioned area.

\section{Authors' contributions}

Experiments designated and conceived: WM Mangrio \& HA Sahito. Experiments performed: WM Mangrio \& FA Jatoi. Data analyzed: WM Mangrio, HA Sahito \& T Kousar, Contributed analysis tools/ materials/ reagents: WM Mangrio \& $\mathrm{ZH}$ Shah. Wrote the paper: WM Mangrio \& HA Sahito.

\section{Acknowledgments}

The scholars are cheerfully thankful to the local peoples of taluka Mehrabpur, villagers, town dwellers of this region by participating in this research work for a collection of hosts to their surroundings because they provided gathered support to authors in hot and summer season of the years. The authors are again thankful to the farmers who given cages for the purpose to keep the bird alive inside them and providing tricks and techniques in capturing the $T$, striata birds from their croplands. Authors are really thankful for their guide, who gives such a pathway way and guide in this work each and every moment.

\section{References}

1. Clements J (2007). Clements Checklist of Birds of the World. 6th edition. New York: Cornell University Press. Available online at http://www.birds.cornell.edu/clementsc hecklist/downloadable-clementschecklist

2. Newton I (2003).The contribution of some recent research on birds to ecological understanding. $J$ Animal Ecology 64(6): 675-696.

3. Bird life International (2013). Checklist of birds of Sindh. Handbook of Birds of World.birds. Pak J Zool 38(1): 21-25.

4. Khan MZ (2005). Wetlands of Sindh with reference to the Ramsar sites in. $J$ Nat Hist Wild 4(2): 141-145.

5. Gill F \& Donsker D (eds). (2012). IOC World Bird Names (v 3.1). Available at http://www.worldbirdnames.org

6. Ali Z (2006). Avian species analysis at three major wetlands complex Pakistan. Biologia Pakistan 2(2): 203213.

7. Ghalib SA, Rehman H \& Khan AR (2006). Observation on the Wildlife of Nara Wetland Complex Tehsil Nara District Khairpur, Sindh with special 
Reference to the Water birds. Pak $J$ zool 38(1): 21-25.

8. Ahmed MF \& Ghalib SA (1986). A field guide to the ducks, and swans of Pakistan. Zool Surv of Pakistan 322.

9. Gabol K (2004). Some observation on the birds of Hadero lake Sindh. J. Biol Sci 4: 5-8.

10. Bhavna B \& Geeta P (2010). Histological and histomorphometric study of gametogenesis in breeders and helpers of sub-tropical, co-operative breeder jungle babbler, Turdoides striatus. J Cell Anim Biol 4: 81-90.

11. Yule H (1903). William Crooke, ed. Hobson-Jobson . A glossary of colloquial Anglo-Indian words and phrases of kindred terms etymological, historical, geographical and discursive. London. J. Murray 1021.

12. Bharucha B \& Padate GS (2010). Assessment of beneficial role of an insectivorous bird, jungle babbler (Turdoides striatus) predation, on Helicoverpa armigera infesting pigeon pea (Cajanus cajan) crop. Acta Agron 59: 228-235.

13. Robinette RL \& Ha JC (2001). Social and ecological factors influencing vigilance by northwestern crows, Corvus caurinus. Anim Behav 62: $447-$ 452.

14. Narang ML \& Lamba BS (1986). Food habits of jungle babbler Turdoides striatus (Dumont) and its role in the ecosystem. Indian J Ecology 13(1): 3845.

15. Devasahayam $S$ \& Adevasahayam (1991). Aggressive behaviour of Jungle Babblers Turdoides striatus (Dumont) towards a snake. $J$ Bombay Nat Hist Soc 88 (2): 288.

16. Andrew MI \& Naik RM (1965). Structural basis of the change of eye colour of the Jungle babbler, Turdoides striata (Dumont), during postembryonic development. Pavo 3: 7274.

17. Gaston AJ (1977). Social behaviour within groups of Jungle Babblers (Turdoides Striatus). Anim Behav 25: 828-848.
18. Neelakantan KK (1957). Hypnotic behaviour of a White-headed Babbler (Turdoides striatus). J Bombay Nat Hist Soc 54 (2): 460-461.

19. Johnsingh AJT, Paramanandham K \& Murali S (1983). Foraging behaviour and interactions of Whiteheaded Babbler Turdoides affinis with other species. $J$ Bombay Nat. Hist Soc 79 (3): 503-514.

20. Zacharias VJ \& Anil Mathew DN (1988). Ecology of Babblers (Turdoides spp.) J Bombay Nat Hist Soc 85 (1): 50-63.

21. McSorley JH \& Rick MM (2012). Helminth infection and host Immune Regulation. Clin Microbiol Rev 25(4): 585-608.

22. Adang KL, Oniye SJ, Ezealor AU, Abdu PA, Ajanusi OJ \&Yoriyo KP (2009). Ectoparasites and gastrointestinal helminths of Black-billed wood dove (Turtur abyssinicus) and Vinaceous dove (Streptopelia vinacea) Hartlaub and Finsch 1870 in Zaria, Nigeria. The Pacific $J$ Sci and Tech 10(2): 850-856.

23. Diakou A \& Papadopoulos SE (2013). Cestode fauna of feral pigeons in Thessaloniki, Northern Greece. Helminthologia 50(1): 39-42.

24. Hussen H, Chaka H, Deneke Y \& Bitew M (2012). Gastrointestinal helminths are highly prevalent in scavenging chickens of selected districts of Eastern shewa zone, Ethiopia. Pak J Biol Sci 15(6): 284289.

25. Naphade ST \& Chaudhari KV (2013). Studies on the seasonal prevalence of parasitic helminths in Gavran (Desi) Chickens from Marathwada region of Maharashtra. IJFBS 1(2): 4-7

26. Shahin AM, Lebdah MA, Abu-Elkheir SA \& Elmeligy MM (2011). Prevalence of chicken cestodiasis in Egypt. New York Sci J 4(9): 21-29.

27. Halajian A, Eslami A, Mobedi I, Amin O, Mariaux J, Mansoori J \& Tavakol S (2011). Gastrointestinal helminths of Magpies (Pica pica), Rooks (Corvus frugilegus) and Carrion Crows (Corvus 
corone) in Mazandaran Province, North Iran. Iran J Para 6(2): 38-44.

28. Baugh SC (1949). On a new avian trematode, Psilorchisthapari, (from, Psilostomidae) with a record of Psilochasmusoxyarus (Crep.) from India. Indian J Helminthol 1(2): 79-84.

29. Sivajothi S \& Sudhakara RB (2015). A study on the gastro intestinal parasites of domestic Pigeons in YSR Kadapa District in Andhra Pradesh, India. $J$ Dairy Veterinary and Animal Res 2(6): 1-3.

30. Zhang X, Qiao JY, Wu XM, Ma QY, $\mathrm{Hu} \mathrm{H}$, Wang J \& Che LF (2014). Ascaris spp. and Capillaria caudinflata Infections in Captive Bred Crested Ibis (Nipponia nippon) in China. Zoo Biol 34: 80-84.

31. Lee CC \& Amin-babjee SM (1993). New Host Records of Parasites in the Malayan Red jungle fowl, Gallus gallus spadiceus. Pertanika J Trop Agric Sci 16(2): 107-110.

32. Sadiq A (2014). Ectoparasites and helminth parasites of Columbidae in Logos State. Avian Para 1-11.

33. Mangrio WM, Sahito HA, Ruk M, Shah ZH \& Kanher KA (2016). Impact of cestode Helminth, Hymenolepis spp. (Weinland, 1858) in Jungle babbler bird. $36^{\text {th }}$ Zoological Conf (International) held on 16-18, Feb. 2016.

34. Bilqees FM (1985). Cestodes of vertebrates in Pakistan. Pro Para 1: 39-144.

35. Naphade ST (2013). Studies on the prevalence of helminthic infection in broiler Poultry birds from Marathwada Region, (MS) India. Sci Res Rep, 3(2): 233-238.

36. Bahrami AM, Hosseini E \& Razmjo M (2013). Important parasite in pigeon, its hematological parameter and pathology of intestine. World Appl Sci $J$ 21(9): 1361-1365.

37. Offiong EEA, Obioku OE, Umoh JU, Essien CA \& Idiong NB (2013). A survey of gastrointestinal helminths of local chickens in Abak local government area of Akwa Ibom State. IJSBAR 9(1): 1-4.

38. Percy J, Pias M, Enetia BD \& Lucia T (2012). Seasonality of parasitism in free range chickens from a selected ward of a rural district Zimbabwe. Afri J Agri Rese 7(25): 3626-3631.

39. Darrel KS (1996). Antimicrobials commonly used in avian medicine Part 4: Antifungals, anthelmintics, and antiprotozoals. In Old World Aviaries Antimicrobial. Hill Country Aviaries L LC 33-34.

40. Hegngi FN, Doerr J, Cummings TS, Schartz RD, Saunders G, Zajac A, Larsen CT, Piersen FW (1999). The effectiveness of benzimidazole derivatives for the treatment and prevention of histomoniasis (blackheaded birds) in Turkey. Vet Parasitol 81(1): 29-37.

41. Sahito HA, Mangrio WM, Kousar T, Shah ZH \& Sohu TA (2016). Subulura suctoria, Molin, 1860, nematode from Jungle babbler (Turdoides striata) at Sindh, Pakistan. J. Entomology and Zoology Stu 4(5): 950-955.

42. Mangrio WM, Sahito HA, Kousar T, Jatoi FA, Shah ZH, Mallah NA, \& Kubar WA (2017). Prevalence and morphotaxonomic characteristic of nematode, Contracaecum travassosi (Gutierrez, 1943) from bird jungle babbler, Turdoises striata. J. Adv. in Medical and Life Sci 5(2): 1-5.

43. Sahito HA, Mangrio WM, Kousar T, Jatoi FA, Ghumro BD, Bhutto SR \& Pitafi TA (2017). Assessment and Morphological characteristics of Oligorchis kandiariansis n. sp., from Turdoides striata, 1823 (Leiothrichidae) in Sindh-Pakistan. $J$ Adv Bot and Zool 5(2): 1-5.

44. Mangrio WM, Sahito HA, Kousar T, Azizullah, Jatoi FA, Shah ZH \& Ghumro BD (2017). Pervasiveness and different characteristics of Cestode, Confluaria capillaris (Rudolphi, 1810) from Jungle babbler, Turdoides striata at Sindh, Pakistan. Inter. J Res Studies in Zool 3(3): 33-43. 